\title{
Estimation of phenolic compounds and antioxidant capacity in leaves of fruit species using near-infrared spectroscopy and a chemometric approach
}

\author{
Darly Rodrigues Pompeu ${ }^{(1)}$, Audrey Pissard ${ }^{(4)}$, Hervé Rogez ${ }^{(3)}$, Pascal Dupont ${ }^{(2)}$, \\ Marc Lateur ${ }^{(2)}$, Vincent Baeten ${ }^{(4)}$ \\ (1) Universidade do Estado do Pará. Centre of Natural Science and Technology. Department of Food Technology. Travessa \\ Éneas Pinheiro, 2626. 66.095-100 Belém-PA (Brazil). \\ (2) Walloon Agricultural Research Centre (CRA-W). Life Sciences Department. Rue de Liroux, 4. BE-5030 Gembloux \\ (Belgium). \\ (3) Universidade Federal do Pará \& Centre for Agro-food Valorisation of Amazonian Bioactive Compounds (CVACBA). \\ Avenida da Ciência, km 01. 66.095-780 Belém-PA (Brazil). \\ (4) Walloon Agricultural Research Centre (CRA-W). Valorisation of Agricultural Products Department. Chaussée de Namur, \\ 24. BE-5030 Gembloux (Belgium).E-mail: a.pissard@cra.wallonie.be
}

Received 6 April 2020, accepted 26 April 2021, available online 18 May 2021.

This article is distributed under the terms and conditions of the CC-BY License (http://creativecommons.org/licenses/by/4.0)

Description of the subject. Phenolic compounds are very important to the antioxidant capacity of plant species. Phenolic compounds and hence antioxidant capacity are commonly measured in the laboratory using indirect methods that involve several stages and chemicals.

Objectives. This study aims to identify species with high content of phenolic compounds and antioxidant capacity and to measure these parameters in the leaves of fruit species using near-infrared spectroscopy (NIRS).

Method. A total of 68 samples of different varieties of Prunus avium, Prunus cerasus, Malus domestica, Prunus domestica, Pyrus communis, Vitis vinifera, Ficus carica and Corylus avellana were investigated. The dried ground leaves were scanned in reflectance mode and the phenolic compound content (total phenolic compounds, total flavanols and total flavonols) and antioxidant capacity (2-2-diphenyl-1-picrylhydazil [DPPH] and oxygen radical absorbance capacity [ORAC]) were determined. Results. Great variability of phenolic compound content and antioxidant capacity was observed between species (inter-species) and between varieties (intra-species). The spectra with and without pre-treatments were tested to correlate with the phenolic compound content and antioxidant capacities. The pre-treatments tested showed a slight improvement in statistical parameters $\left(\mathrm{R}_{\mathrm{CAL}}^{2}>0.75 ; \mathrm{R}_{\mathrm{CV}}^{2}>0.21 ; \mathrm{RPD}>1.1\right)$.

Conclusions. The results suggest that NIR spectroscopy with chemometric approaches could be used to rapidly estimate the phenolic compound content and antioxidant capacity of the leaves of fruit species. The species evaluated in this study were shown to be a rich source of phenolic compounds and antioxidants.

Keywords. Leaves, fruit trees, phenolic compounds, antioxidants, near infrared spectroscopy.

Estimation des composés phénoliques et de la capacité antioxydante des feuilles d'espèces fruitières par spectroscopie proche infrarouge et approche chimiométrique

Description du sujet. Les composés phénoliques sont très importants pour la capacité antioxydante des espèces végétales. Les composés phénoliques et donc la capacité antioxydante sont généralement mesurés en laboratoire en utilisant des méthodes indirectes qui impliquent plusieurs étapes et produits chimiques.

Objectifs. Cette étude vise à identifier les espèces à hautes teneurs en composés phénoliques et capacité antioxydante et à mesurer ces deux paramètres dans les feuilles d'espèces fruitières à l'aide de la spectroscopie proche infrarouge (NIRS).

Méthode. Un total de 68 échantillons de différentes variétés de Prunus avium, Prunus cerasus, Malus domestica, Prunus domestica, Pyrus communis, Vitis vinifera, Ficus carica et Corylus avellana ont été étudiés. Les feuilles séchées et broyées ont été scannées en mode réflectance et la teneur en composés phénoliques (polyphénols totaux, flavanols totaux et flavonols totaux), la capacité antioxydante (2-2-diphényl-1-picrylhydazil [DPPH] et la capacité d'absorption des radicaux d'oxygène [ORAC]) ont été déterminés. 
Résultats. Une grande variabilité de la teneur en composés phénoliques et de la capacité antioxydante a été observée entre les espèces (inter-espèces) et entre les variétés (intra-espèce). Les spectres, avec et sans prétraitements, ont été corrélés avec la teneur en composés phénoliques et la capacité antioxydante. Les prétraitements ont montré une légère amélioration des paramètres statistiques $\left(\mathrm{R}_{\mathrm{CAL}}^{2}>0,75 ; \mathrm{R}_{\mathrm{CV}}^{2}>0,21 ; \mathrm{RPD}>1,1\right)$.

Conclusions. Les résultats suggèrent que la spectroscopie proche infrarouge couplée à la chimiométrie pourrait être utilisée pour estimer rapidement la teneur en composés phénoliques et la capacité antioxydante des feuilles d'espèces fruitières. Les espèces évaluées dans cette étude se sont révélées être une source riche en composés phénoliques et en agents antioxydants.

Mots-clés. Feuilles, arbres fruitiers, composés phénoliques, antioxydant, spectroscopie proche infrarouge.

\section{INTRODUCTION}

Phenolic compounds (PCs) are the most abundant secondary metabolites of plants. They comprise a wide variety of molecules that have a phenolic structure. They are classified according to the number of phenol rings that they contain and to the structural elements that bind these rings, forming six categories:

- hydroxybenzoic acids;

- hydroxycinnamic acids and coumarins;

- flavonoids (anthocyanins, flavanols, flavanones, flavanonols, flavones, flavonols and isoflavones);

- stilbenes;

- curcuminoids;

- secoridoids (Robards et al., 1999; Ignat et al., 2011).

PCs are associated with increased antioxidant capacity in plant species (Robards et al., 1999; Ignat et al., 2011). The health benefits and effectiveness of PCs as antioxidant compounds have been summarized by many authors illustrating their importance in the scientific world (Lorenzo \& Munekata, 2016).

There are many in vitro methods used to determine antioxidant capacity. PCs as antioxidants can deactivate radicals by three major mechanisms: electron transfer (ET) (for instance, 2,2-diphenyl-1-picrylhydrazyl radical $[\mathrm{DPPH}]$ assay and the Folin-Ciocalteu assay), hydrogen atom transfer (HAT) (for example, oxygen radical absorbance capacity [ORAC] assay), and the scavenging of reactive species (MacDonald-Wicks et al., 2006).

The PCs contents and antioxidant capacities of the leaves of fruit species have been investigated in the last years (for instance, leaves of Malus domestica Borkh., Pyrus communis L., Corylus avellana L. and Ficus carica L.). However, most of the studies focused on few varieties for each species (Amaral et al., 2005; Alasalvar et al., 2006; Oliveira et al., 2007; Mikulic-Petkovsek et al., 2009; Allahyari et al., 2014; Zbigniew et al., 2014; Ammar et al., 2015; Rana et al., 2016; Sklodowska et al., 2017; Petruccelli et al., 2018; Parvaneh et al., 2019). Rarely more than 10 varieties per species were studied (Amaral et al., 2010). Moreover, the methodology used for the antioxidant capacity based generally on a single mechanism (Allahyari et al., 2014; Ammar et al., 2015).
Despite the fact that PCs present some advantages as antioxidants, their quantification and identification are time-consuming and costly. Current methods could not be used for real-time measurements and their application in loco to raw material testing is very limited. They are indirect methods that involve several stages (freeze-drying, homogenization, multi-step solvent extractions, solid-phase extraction or liquid-liquid extraction, and clean-up) before phenolic compounds can be measured (de Rijke et al., 2006; Naczk \& Shahidi, 2006). Furthermore, several reagents/solvents are used in these stages, making these methods environmentally harmful.

In this sense, near-infrared spectroscopy (NIRS) has proved to be a fast, simple, non-destructive and chemical-free analytical tool that can be applied in the field or online and can complement chemical analysis. It can also be used as an analytical tool to analyze and investigate plant species with the potential to be used as a source of PCs.

The use of NIRS to determine total phenolic compounds, individual phenolic compounds and antioxidant capacity in leaves has been extensively reported in the literature especially for Camellia sinensis (L.) Kuntze (Schulz et al., 1999; Chen et al., 2008; Ren et al., 2013; Wang et al., 2018). NIRS has also been used to quantify phenolic compounds and/ or antioxidant capacity in leaves and aerial parts of other plant species. Wu et al. (2012) pointed to the potential for the use of NIRS to inspect the antioxidant capacity (DPPH method) in bamboo leaves. Dong et al. (2014) concluded that NIRS is a very attractive and convenient alternative for the simultaneous analysis of total phenolic compounds, total flavanols and DPPH antioxidant capacity of mint samples. Frizon et al. (2015) made effective use of NIRS to quantify total phenolic compounds in samples of yerba mate (Ilex paraguariensis A.St.-Hil.). Ma et al. (2016) used NIRS for the rapid quantification of the total phenolic compounds and antioxidant capacity (DPPH method) of Dendrobium officinale Kimura \& Migo, a Chinese herb. Souza et al. (2017) investigated the feasibility of NIRS for quantifying total phenolic compounds and total flavanols in aerial parts of Secale cereal L., Avena strigosa Schreb. and Raphanus sativus L. ToledoMartín et al. (2017) also applied visible and NIR 
spectroscopy to quantify total phenolic compounds in rocket leaves (Eruca vesicaria [L.] Cav.). Recently, Can et al. (2018) used NIRS to quantify total phenolic compounds, total flavanols and DPPH antioxidant capacity in leaves of Olea europaea L.

Despite the wide range of investigated species, NIRS has never been used on leaves of fruit species such as Prunus avium (L.) L. (sweet cherry), Prunus cerasus L. (sour cherry), M. domestica (apple), Prunus domestica L. (plum), P. communis (pear), Vitis vinifera L. (vine), F. carica (fig), and C.avellana (hazel). Therefore this study had two objectives:

- to identify new sources of phenolic compounds and antioxidant capacity in leaves of these fruit species not yet studied;

- to estimate phenolic compound content (total phenolic compounds, total flavanols and total flavonols) and antioxidant capacity based on ET (DPPH) and HAT (ORAC) using NIRS methods.

So far as we know, this is the first study focusing on determining phenolic compound content and antioxidant capacity by NIRS in the leaves of these species.

\section{MATERIALS AND METHODS}

\subsection{Plant materials}

Leaves of varieties of P. avium (Abbesse de Mouland, Cerise de Lignette, Reine Hortense, Bigarreau Noir Hâtif, Bigarreau Blanc Hâtif, Belle Magnifique, "Cerise Noire sucrée", Guigne "Very Wéron", Pirette de Biercée, Cerise "Jaune et Rose"), P.cerasus (Morina, Griotte de Schaerbeek, Griotte de Schaerbeek AR1, Griotte de Schaerbeek AR2, Griotte d'Italie), M. domestica (Geneva, Kermerrien, Pilot, Jonagold, Braeburn, Coxybelle, Gueule de Mouton, Président Van Dievoet, Reinette de Waleffe, Pomme Quenique, CRA-W-Ma-BF32, CRA-W-Ma-BF25, CRA-W-MaAF34), Malus floribunda Siebold ex Van Houtte, Malus sieboldii (Regel) Rehder, P. domestica (Reine-Claude d'Althan Falso, Reine-Claude d'Althan, Anastasia, Type Altesse simple, Sainte-Catherine, Reine-Claude Violette, Mirabelle jaune, Prune Passe-Abricot, Altesse Dorée, Washington, Prune de Prince, Belle de Thuin, Wignon, Prune Oeuf d'Oie, Prune Amère), P. communis (Bloedpeer, Bronzée d'Enghien, Double de Guerre, Louis Grégoire, Nicolas Panaché, Nouveau Poiteau, Poire de la Capelle, Poire de Malade, Tardive de Ninove, Carisi, Fondante de Malines, Poire de Gros, Pomme-Poire, Gros Blanquet, Beurré Superfin), V. vinifera ("Pourpre Quintinie", Pinot Noir, "Gros Rouge Hex" Boskoop Glory), F. carica (Figue Jaune, Longue du Portugal, Goutte d'Or) and one variety of C.avellana ("Noisetier Pourpre Marchal") were employed in this study (68 samples in total) (Table 1). All samples were picked from the collections of the Centre wallon de Recherches Agronomiques (CRA-W) in Gembloux, Belgium. All trees were grown on the same type of soil and subjected to standard horticultural practices. The leaves were collected at a mature stage (September) and were chosen by selecting the fifth leaf from the apex (from one-year-old shoots). The collected leaves were transported in a refrigerated box to the laboratory of CRA-W. The samples were dried in a forced-air oven at $50{ }^{\circ} \mathrm{C}$ until constant weight (around $2 \mathrm{~h}$ ), then ground into a homogeneous powder. This powder was used for all analysis. For the statistical analyses, data related to the cherry species i.e. both $P$. avium and $P$. cerasus were gathered together under $P$. avium. In the same way, data related to $M$. floribunda and $M$. sieboldii were included with the $M$. domestica samples.

\subsection{NIR acquisitions}

The ground leaves were scanned with a Fourier Transform near-infrared spectrometer (MPA, BRUKER Optics, Ettlingen, Germany) in reflectance mode. Their reflectance spectra were obtained using the software OPUS, version 6.50. Each sample was scanned with two replicates in a ring cup (internal diameter $35 \mathrm{~mm}$, depth $8 \mathrm{~mm}$ ) and the mean spectra of each samples was used $(n=68)$. The spectra were collected continuously over a wavelength range from 1,100 to $2,498 \mathrm{~nm}$ and were recorded as absorbance value at $2 \mathrm{~nm}$ increments. The measurements were carried out at room temperature $\left(20 \pm 2^{\circ} \mathrm{C}\right)$ and the spectrum of each sample was the average of 64 scans (Osborne, 2006; Minet et al., 2021).

\subsection{Extraction procedure for phenolic compound content and antioxidant capacities}

The ground leaves were extracted by shaking at $25 \pm 2{ }^{\circ} \mathrm{C}$ for $30 \mathrm{~min}$ with an acidified aqueous acetone solution 79.5:20:0.5 (v:v:v; acetone:water:acetic acid). Then, the extracts were centrifuged $(8,000 \mathrm{rpm} \mathrm{g}$ at $4{ }^{\circ} \mathrm{C}$ for $20 \mathrm{~min}$ ), and the supernatant was used to determine the phenolic compound content and antioxidant capacity.

\subsection{Phenolic compound determination}

Total phenolic compounds. The total phenolic compound content was determined by the FolinCiocalteu method, following the procedure proposed by Singleton \& Rossi (1965). The total phenolic compound content was expressed as mg of gallic acid equivalent (GAE) per $g$ of dry weight (DW). 
Table 1. Species and varieties used in this study - Espèces et variétés analysées dans cette étude.

\begin{tabular}{|c|c|}
\hline Species & Variety \\
\hline Prunus avium & $\begin{array}{l}\text { Abbesse de Mouland } \\
\text { Cerise de Lignette } \\
\text { Reine Hortense } \\
\text { Bigarreau Noir Hâtif } \\
\text { Bigarreau Blanc Hâtif } \\
\text { Belle Magnifique } \\
\text { Cerise "Noire sucrée" } \\
\text { Guigne "Very Wéron" } \\
\text { Pirette de Biercée } \\
\text { Cerise "Jaune et Rose" }\end{array}$ \\
\hline Prunus cerasus & $\begin{array}{l}\text { Morina } \\
\text { Griotte de Schaerbeek } \\
\text { Griotte de Schaerbeek AR1 } \\
\text { Griotte de Schaerbeek AR2 } \\
\text { Griotte d'Italie }\end{array}$ \\
\hline Malus domestica & $\begin{array}{l}\text { Geneva } \\
\text { Kermerrien } \\
\text { Pilot } \\
\text { Jonagold } \\
\text { Braeburn } \\
\text { CRA-W-Ma-AF34 } \\
\text { Coxybelle } \\
\text { Gueule de Mouton } \\
\text { Président Van Dievoet } \\
\text { Reinette de Waleffe } \\
\text { CRA-W-Ma-BF32 } \\
\text { CRA-W-Ma-BF25 } \\
\text { Pomme Quenique }\end{array}$ \\
\hline Malus sieboldii & Malus sieboldii \#1897 \\
\hline Malus floribunda & Malus floribunda \#821 \\
\hline Vitis vinifera & $\begin{array}{l}\text { "Pourpre Quintinie" } \\
\text { Pinot Noir } \\
\text { "Gros Rouge Hex" } \\
\text { Boskoop Glory }\end{array}$ \\
\hline Prunus domestica & $\begin{array}{l}\text { Reine-Claude d'Althan Falso } \\
\text { Reine-Claude d'Althan } \\
\text { Anastasia } \\
\text { Type Altesse simple } \\
\text { Sainte-Catherine } \\
\text { Reine-Claude Violette } \\
\text { Mirabelle jaune } \\
\text { Prune Passe-Abricot } \\
\text { Altesse Dorée } \\
\text { Washington } \\
\text { Prune de Prince } \\
\text { Belle de Thuin } \\
\text { Wignon } \\
\text { Prune Oeuf d'Oie } \\
\text { Prune Amère }\end{array}$ \\
\hline Pyrus communis & $\begin{array}{l}\text { Bloedpeer } \\
\text { Bronzée d'Enghien } \\
\text { Double de Guerre } \\
\text { Louis Grégoire }\end{array}$ \\
\hline
\end{tabular}

Table 1 (continued). Species and varieties used in this study - Espèces et variétés analysées dans cette étude.

\begin{tabular}{ll}
\hline Species & Variety \\
\hline Pyrus communis & Nicolas Panaché \\
& Nouveau Poiteau \\
& Poire de la Capelle \\
& Poire de Malade \\
& Tardive de Ninove \\
& Carisi \\
& Fondante de Malines \\
& Poire de Gros \\
& Pomme-Poire \\
& Gros Blanquet \\
& Beurré Superfin \\
\hline Corylus avellana & "Noisetier Pourpre Marchal" \\
\hline \multirow{2}{*}{ Ficus carica } & Figue Jaune \\
& Longue du Portugal \\
& Goutte d'Or \\
\hline
\end{tabular}

Total flavanols. The total flavanols were estimated using the chromogen p-dimethylaminocinnamaldehyde (DMACA) (SIGMA), following the protocol proposed by Delcour \& Devarebeke (1985). The total flavanol content was expressed as $\mathrm{mg}$ of catechin equivalent (CE) per $g$ of DW.

Total flavonols. The quantification of flavonols was determined using the aluminum chloride colorimetric method following the procedure described by Chang et al. (2002). The total flavonol content was expressed as mg of quercetin equivalent (QE) per $\mathrm{g}$ of $\mathrm{DW}$.

\subsection{Antioxidant capacity determination}

The 2-2-diphenyl-1-picrylhydazil (DPPH) method. The antioxidant capacity of 2-2-diphenyl-1-picrylhydazil (DPPH) was determined using a protocol adapted from Brand-Williams et al. (1995). The DPPH antioxidant capacity was expressed as $\mu$ mol of trolox equivalent (TE) per $g$ of DW.

The oxygen radical absorbance capacity (ORAC) method. The oxygen radical absorbance capacity assay, using fluorescein as the fluorescent probe, was performed on a microplate fluorimeter. The procedure used was that described by Silva et al. (2007) and was an adaptation of the protocols proposed by $\mathrm{Ou}$ et al. (2001) and Huang et al. (2002). The ORAC was expressed as $\mu \mathrm{mol}$ of trolox equivalent (TE) per $\mathrm{g}$ of DW. Each sample was measured in triplicate.

\subsection{Data processing}

NIR spectral data were analyzed using the software The Unscrambler X (CAMO, Trondheim, Norway). 
Different pre-treatments were applied to NIR spectra (baseline, detrend, first and second derivatives, multiplicative scatter correction [MSC], smoothing, standard normal variate [SNV]) individually or in combination. The first and second derivatives and smoothing pre-treatments were performed using the algorithm of Savitzky-Golay (5 points and second-order filtering). The partial last square (PLS) regression method was applied to correlate phenolic compound content and antioxidant capacity to spectra. Due to the limited number of samples in the data, full cross-validation was applied as a validation method. The optimum number of factors was determined applying the root mean standard error (RMSE) and standard error (SE). The RPD value (ratio of prediction to deviation) was also calculated. RPD is the ratio of the SD (standard deviation) to the RMSE of crossvalidation.

\subsection{Statistical analysis}

The results of the phenolic compound content and antioxidant capacity measurements were expressed as mean value \pm standard deviation (mean $\pm \mathrm{SD}$ ). Analysis of variance (ANOVA), significance (Tukey) and correlation (Pearson) tests were performed using the STATISTICA 13.5 (TIBCO Software Inc., 2018) for Windows. Variables with a confidence level higher than $95 \%(p<0.05)$ were considered as significant.

\section{RESULTS}

\subsection{Phenolic compound content and antioxidant capacity}

In order to quantify the phenolic compound content and antioxidant capacity in leaves of some common largest fruit species, varieties of P.avium, M.domestica, P.domestica, P.communis, V.vinifera, F.carica and $C$.avellana were analyzed. The total phenolic compound, flavanol and flavonol contents as well as the antioxidant capacity measured by methods based on ET (DPPH) and HAT (ORAC) are presented in Table 2.

The lowest and highest values for the total phenolic compound, total flavanol and total flavonol contents in leaves of fruit species were as follows: 8.19 (F. carica variety Figue Longue du Portugal) and $94.13 \mathrm{mg}$ GAE $\cdot \mathrm{g}^{-1} \mathrm{DW}$ (P. communis variety Double de Guerre); 0.13 (F.carica variety Figue Jaune) and $17.06 \mathrm{mg}$ $\mathrm{CE} \cdot \mathrm{g}^{-1}$ DW (C.avellana); and 4.57 (M.domestica variety Gueule de Mouton) and $173.53 \mathrm{mg} \mathrm{QE} \cdot \mathrm{g}^{-1} \mathrm{DW}$ ( $P$. avium variety Bigarreau Noir Hâtif), respectively.

For the antioxidant capacities, the DPPH values ranged from 2.91 (F. carica variety Longue du Portugal) to $88.28 \mu \mathrm{M} \mathrm{TE} \cdot \mathrm{g}^{-1} \mathrm{DW}$ (P. communis variety Double de Guerre). The ORAC antioxidant capacity values ranged from 508.9 (F. carica variety Figue Goutte d'Or) to $10,508.2 \mu \mathrm{M} \mathrm{TE} \cdot \mathrm{g}^{-1} \mathrm{DW}$ (M. sieboldii).

Table 2. The phenolic compound content and antioxidant capacity of leaves of Prunus avium, Malus domestica, Prunus domestica, Pyrus communis, Vitis vinifera, Ficus carica and Corylus avellana of different varieties - Contenu en polyphénols totaux et capacité antioxydante de feuilles de différentes variétés de Prunus avium, Malus domestica, Prunus domestica, Pyrus communis, Vitis vinifera, Ficus carica et Corylus avellana.

\begin{tabular}{|c|c|c|c|c|c|c|}
\hline \multirow[t]{2}{*}{ Species } & \multirow[t]{2}{*}{$n$} & \multicolumn{3}{|c|}{ Phenolic compound } & \multicolumn{2}{|c|}{ Antioxidant capacity } \\
\hline & & $\begin{array}{l}\text { TPC } \\
\left(\mathrm{mg} \mathrm{GAE} \cdot \mathrm{g}^{-1} \mathrm{DW}\right)\end{array}$ & $\begin{array}{l}\text { TFAL } \\
\left(\mathrm{mg} \mathrm{CE} \cdot \mathrm{g}^{-1} \mathrm{DW}\right)\end{array}$ & $\begin{array}{l}\text { TFOL } \\
\left(\mathrm{mg} \mathrm{QE} \cdot \mathrm{g}^{-1} \mathrm{DW}\right)\end{array}$ & $\begin{array}{l}\text { DPPH } \\
\left(\mu \mathrm{M} \text { TE } \cdot \mathrm{g}^{-1} \mathrm{DW}\right)\end{array}$ & $\begin{array}{l}\text { ORAC } \\
\left(\mu \mathrm{M} \text { TE } \cdot \mathrm{g}^{-1} \mathrm{DW}\right)\end{array}$ \\
\hline Prunus avium & 15 & $54.68 \pm 12.72^{\mathrm{b}}$ & $8.68 \pm 3.51^{\mathrm{c}}$ & $30.57 \pm 40.18^{\mathrm{a}}$ & $37.41 \pm 9.31^{\mathrm{bc}}$ & $2,260.3 \pm 967.4^{\mathrm{ab}}$ \\
\hline Malus domestica & 15 & $65.86 \pm 10.18^{b}$ & $3.42 \pm 2.23^{\mathrm{ab}}$ & $16.00 \pm 8.57^{\mathrm{a}}$ & $32.15 \pm 18.08^{b}$ & $4,467.0 \pm 2,290.5^{c}$ \\
\hline Pyrus communis & 15 & $58.39 \pm 11.91^{\mathrm{b}}$ & $5.13 \pm 2.77^{\mathrm{ab}}$ & $16.73 \pm 4.42^{\mathrm{a}}$ & $44.66 \pm 14.54^{\mathrm{bc}}$ & $3,844.6 \pm 1,099.0^{\text {bc }}$ \\
\hline Prunus domestica & 15 & $74.20 \pm 14.54^{b}$ & $6.10 \pm 2.85^{\mathrm{bc}}$ & $20.16 \pm 5.87^{\mathrm{a}}$ & $49.51 \pm 15.84^{c}$ & $2,709.6 \pm 1,153.0^{\mathrm{ab}}$ \\
\hline Vitis vinifera & 4 & $55.23 \pm 12.13^{\mathrm{b}}$ & $5.31 \pm 3.73^{\mathrm{abc}}$ & $16.70 \pm 0.93^{\mathrm{a}}$ & $37.54 \pm 8.59^{\mathrm{bc}}$ & $897.3 \pm 347.8^{\mathrm{a}}$ \\
\hline Ficus carica & 3 & $11.80 \pm 3.82^{\mathrm{a}}$ & $0.39 \pm 0.30^{\mathrm{a}}$ & $6.54 \pm 2.40^{\mathrm{a}}$ & $5.96 \pm 4.07^{\mathrm{a}}$ & $1,214.3 \pm 1,113.8^{\mathrm{ab}}$ \\
\hline Corylus avellana ${ }^{l}$ & 1 & 77.34 & 17.06 & 14.32 & 48.95 & $3,514.1$ \\
\hline All groups & 68 & $60.74 \pm 17.48$ & $5.73 \pm 3.74$ & $19.89 \pm 20.11$ & $39.31 \pm 16.74$ & $3,087.8 \pm 1,746.5$ \\
\hline
\end{tabular}

TPC: total phenolic compounds - polyphénols totaux; TFAL: total flavanols - flavanols totaux; TFOL: total flavonols - flavonols totaux; DPPH: 2-2-diphenyl-1-picrylhydazil; ORAC: oxygen radical absorbance capacity - capacité d'absorption des radicaux d'oxygène; ${ }^{1}$ : for this species just one variety was investigated - pour cette espèce, une seule variété a été étudiée ; $n$ : number of samples - nombre d'échantillons; mean values with the same letters were not statistically different according to the Tukey test $(p>0.05)$ - les valeurs moyennes avec la même lettre ne diffèrent pas significativement selon le test de Tukey $(\mathrm{p}>0,05)$. 
The variability between varieties was relatively low for total phenolic compounds (a factor of around 2 for all species, except $P$. avium, where it varied by a factor of around 3). By contrast, there was high variability for total flavanols (a factor of around 5.5, except P. avium, where it varied by a factor of around 3.5) and total flavonols (a factor of around 2 for all species, except $P$. avium and $M$. domestica, where it varied by factors of around 23 and 9.5 respectively). For antioxidant capacity, the highest variability between varieties was observed for DPPH (a factor of around 9 for M. domestica), whereas ORAC antioxidant capacity varied by a factor of around 5, except for P. communis and $V$. vinifera (where it varied by a factor of around $2.5)$. The variability between species was greater for phenolic compounds, especially total flavanols (a factor of 134) and total flavonols (a factor of 38), than for antioxidant capacity (factors of 30 for DPPH and 21 for ORAC).

Correlations between phenolic compounds and antioxidant capacity in fruits, vegetables, beverages and herbs have been intensely reported (Apak et al., 2007; Floegel et al., 2011). In this study, total phenolic compounds presented a significant correlation $(p>0.05)$ with total flavanols, total flavonols and antioxidant capacity measured by the ORAC method. Total flavanols presented a significant correlation with total flavonols $(p>0.05)$. Antioxidant capacity measured by the DPPH method did not present any correlation with phenolic compounds or with antioxidant capacity measured by the ORAC method. Table 3 presents the values for Pearson's correlation coefficient obtained in this study.

Table 3. Pearson's correlation coefficient for phenolic compound content and antioxidant capacity in leaves of Prunus avium, Malus domestica, Prunus domestica, Pyrus communis, Vitis vinifera, Ficus carica and Corylus avellana from different varieties - Coefficient de corrélation de Pearson entre le contenu en polyphénols totaux et la capacité antioxydante de feuilles de différentes variétés de Prunus avium, Malus domestica, Prunus domestica, Pyrus communis, Vitis vinifera, Ficus carica et Corylus avellana.

\begin{tabular}{lccccc}
\hline & TPC & TFAL & TFOL & DPPH & ORAC \\
\hline TPC & - & $0.458^{*}$ & $0.575^{*}$ & $-0.004^{\mathrm{NS}}$ & $0.369^{*}$ \\
TFAL & $0.458^{*}$ & - & $0.355^{*}$ & $-0.040^{\mathrm{NS}}$ & $0.086^{\mathrm{NS}}$ \\
TFOL & $0.575^{*}$ & $0.355^{*}$ & - & $-0.073^{\mathrm{NS}}$ & $0.528^{*}$ \\
DPPH & $-0.004^{\mathrm{NS}}$ & $-0.040^{\mathrm{NS}}$ & $-0.073^{\mathrm{NS}}$ & - & $0.190^{\mathrm{NS}}$ \\
ORAC & $0.369^{*}$ & $-0.086^{\mathrm{NS}}$ & $0.528^{*}$ & $0.190^{\mathrm{NS}}$ & - \\
\hline
\end{tabular}

TPC, TFAL, TFOL, DPPH, ORAC : see table 2 - voir

tableau 2; *: Pearson's correlation coefficient significant at $p>0.05-$ coefficient de corrélation de Pearson significatif $\grave{a} \mathrm{p}>0,05 ; \mathrm{NS}$ : not significant $(p<0.05)-$ pas significatif $(\mathrm{p}<0,05)$.

\subsection{Spectra data}

Figure 1 presents the mean spectra obtained for P.avium, M.domestica, P.domestica, P. communis, $V$. vinifera, F. carica and C.avellana from different varieties. Their shapes were very typical of plant material and could be compared with dried green honeybush (Joubert et al., 2006), blueberry (Sinelli et al., 2008), and green tea (Chen et al., 2008). Absorption bands were observed in regions around $1,200,1,450(\mathrm{O}-\mathrm{H}$ stretch first overtone, associated with water), 1,940 (O-H stretch and O-H deformation, associated with water), and 2,100 $\mathrm{nm}$ (C-O stretch and $\mathrm{O}-\mathrm{H}$ stretch combination or $\mathrm{O}-\mathrm{H}$ deformation second overtone) normally associated with water. Some authors have related the influence of the 1,450 and $1,950 \mathrm{~nm}$ bands to phenolic compounds (Joubert et al., 2006; Zhang et al., 2008). Two other bands were also observed, in the region around 1,700 (C-H stretching) and between 2,000 and 2,200 $\mathrm{nm}(\mathrm{O}-\mathrm{H}, \mathrm{C}-\mathrm{H}, \mathrm{C}-\mathrm{O}$ and $\mathrm{C}=\mathrm{O}$ stretching, $\mathrm{O}-\mathrm{H}$ and $\mathrm{C}-\mathrm{H}$ deformation). These bands were also associated with the presence of compounds containing aromatic groups (Joubert et al., 2006).

To correlate phenolic compounds (total phenolic compounds, total flavanols and total flavonols) and antioxidant capacity (DPPH and ORAC) with NIR spectra, partial least square (PLS) regression method was tested with and without pre-treatments. The results of the reference measurements are presented in Table 4. PLS regression was used to develop prediction models for phenolic compounds (total phenolic compounds, total flavanols, and total flavonols) and antioxidant capacity (DPPH and ORAC) using spectral data. Table 5 presents the performance values for calibration and cross-validation $\left(\mathrm{R}_{\mathrm{CAL}}^{2}\right.$, RMSEC, $\mathrm{R}_{\mathrm{CV}}^{2}$, RMSECV, RPD values and the number of factors) obtained for each model developed to predict phenolic compounds and antioxidant capacity. The values of $\mathrm{R}^{2}$ ranged between 0.58 (ORAC - spectral data without pre-treatment) and 0.88 (total flavanols - spectral data with MSC and first derivative pre-treatments) for calibration set and from 0.21 (ORAC - spectral data without pre-treatment) to 0.74 (total phenolic compounds - spectral data with first derivative pre-treatment) for cross validation set. The values of RMSEC and RMSECV are relatively closer. In general, the variation was around $40 \%$, except to ORAC prediction (90\%). The RPD values ranged from 1.13 (ORAC - second derivative) and 1.88 (total phenolic compound - first derivative). The use of pre-treatments decreased the number of factors used in the prediction model and improved all statistical parameters. However, no great improvement was observed in RPD values. In accordance with Nicolaï et al. (2007), the performance parameters obtained in this study could be used to screening 


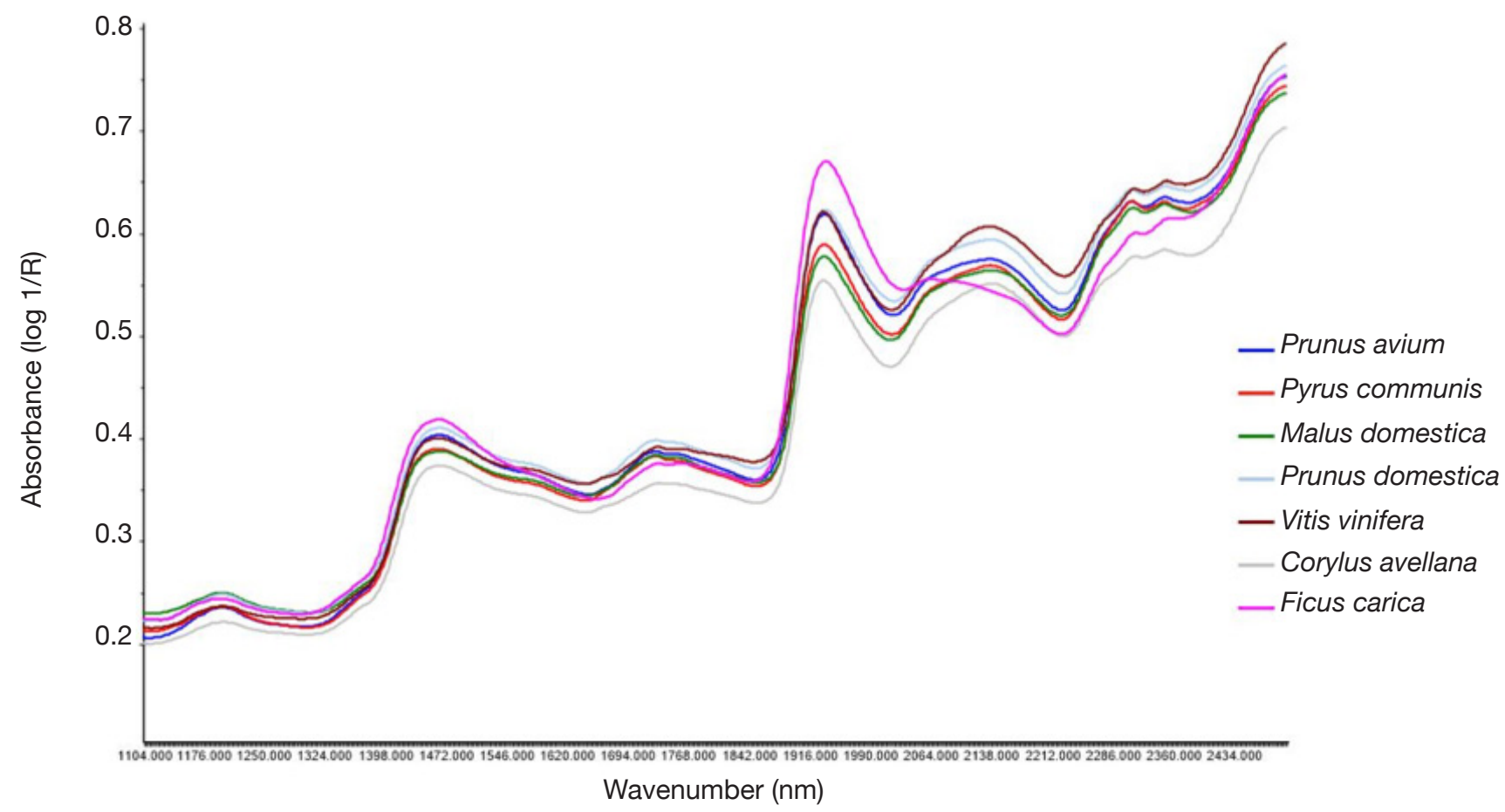

Figure 1. Averaged NIR spectra of ground leaves of Prunus avium, Malus domestica, Prunus domestica, Pyrus communis, Vitis vinifera, Ficus carica and Corylus avellana of different varieties in the 1,100 - 2,500 nm range - Spectres NIR moyennés mesurés à partir de poudre de feuilles de différentes variétés de Prunus avium, Malus domestica, Prunus domestica, Pyrus communis, Vitis vinifera, Ficus carica et Corylus avellana dans la région spectrale de $1100-2500 \mathrm{~nm}$.

Table 4. Reference measurements of phenolic compound content and antioxidant capacity in leaves of Prunus avium, Malus domestica, Prunus domestica, Pyrus communis, Vitis vinifera, Ficus carica and Corylus avellana of different varieties - Valeurs de référence du contenu en polyphénols totaux et de la capacité antioxydante de feuilles de différentes variétés de Prunus avium, Malus domestica, Prunus domestica, Pyrus communis, Vitis vinifera, Ficus carica et Corylus avellana.

\begin{tabular}{lllll}
\hline Parameter & Sample & Average & Standard deviation & Range \\
\hline Total phenolic compound $\left(\mathrm{mg} \mathrm{GAE} \cdot \mathrm{g}^{-1} \mathrm{DW}\right)$ & 68 & 60.74 & 17.48 & $8.19-94.13$ \\
Total flavanols $\left(\mathrm{mg} \mathrm{CE} \cdot \mathrm{g}^{-1} \mathrm{DW}\right)$ & 68 & 5.73 & 3.74 & $0.12-17.06$ \\
Total flavonols $\left(\mathrm{mg} \mathrm{QE} \cdot \mathrm{g}^{-1} \mathrm{DW}\right)$ & 68 & 19.90 & 20.91 & $4.57-173.53$ \\
DPPH $\left(\mu \mathrm{MTE} \cdot \mathrm{g}^{-1} \mathrm{DW}\right)$ & 68 & 39.31 & 16.74 & $2.91-88.28$ \\
ORAC $\left(\mu \mathrm{MTE} \cdot \mathrm{g}^{-1} \mathrm{DW}\right)$ & 68 & $3,087.8$ & $1,746.5$ & $508.9-10,508.2$ \\
\hline
\end{tabular}

and discriminate between low and high values of the estimated parameters.

\section{DISCUSSION}

The results obtained for phenolic compounds and antioxidant capacity in this study show that varieties of fruit species investigated are rich source of phenolic compounds and antioxidant capacity. Their phenolic compound contents represent between 0.82 and $9.4 \%$ of the dry weight of leaves. In a general way, it is difficult to directly compare phenolic compound content and antioxidant capacity between different studies due to variations caused by different extraction procedures (for instance solvent composition, time of extraction, particle size, solid-liquid ratio, temperature, agitation speed), age of plant, agricultural practices, temperature, sun exposure time, growth periods, geographical locations, genetic diversity, and many other factors (Kalinowska et al., 2014). However, the results of some studies are presented in what follows.

For the leaves of M. domestica, Sklodowska et al. (2017) investigated the phenolic profile in leaves of 
Table 5. Statistical parameters of determination of phenolic compound content and antioxidant capacity in leaves of Prunus avium, Malus domestica, Prunus domestica, Pyrus communis, Vitis vinifera, Ficus carica and Corylus avellana of different varieties using NIRS - Paramètres statistiques de la détermination du contenu en polyphénols totaux et de la capacité antioxydante de feuilles de différentes variétés de Prunus avium, Malus domestica, Prunus domestica, Pyrus communis, Vitis vinifera, Ficus carica et Corylus avellana par spectroscopie NIR.

\begin{tabular}{|c|c|c|c|c|c|c|c|}
\hline \multirow[t]{2}{*}{ Parameter } & \multirow[t]{2}{*}{ Pre-treatment } & \multicolumn{2}{|c|}{ Calibration } & \multicolumn{2}{|c|}{ Cross validation } & \multirow[t]{2}{*}{ RPD } & \multirow[t]{2}{*}{ Number of factors } \\
\hline & & $\mathbf{R}^{2}$ & RMSEC & $\mathbf{R}^{2}$ & RMSECV & & \\
\hline TPC & None & 0.810 & 7.57 & 0.671 & 10.11 & 1.72 & 8 \\
\hline Total flavanol & None & 0.747 & 1.87 & 0.540 & 2.54 & 1.46 & 9 \\
\hline Total flavonol & None & - & - & - & - & - & - \\
\hline DPPH & None & 0.697 & 9.15 & 0.473 & 12.32 & 1.35 & 8 \\
\hline ORAC & None & 0.582 & $1,120.2$ & 0.208 & $1,586.8$ & 1.10 & 9 \\
\hline TPC & First derivative & 0.854 & 6.63 & 0.736 & 9.23 & 1.88 & 8 \\
\hline Total flavanol & MSC and first derivative & 0.883 & 1.52 & 0.649 & 2.29 & 1.63 & 8 \\
\hline DPPH & First and second derivatives & 0.816 & 7.13 & 0.619 & 10.66 & 1.56 & 6 \\
\hline ORAC & Second derivative & 0.786 & 802.7 & 0.257 & 1528.4 & 1.13 & 6 \\
\hline
\end{tabular}

TPF: total phenolic compounds - polyphénols totaux; DPPH, ORAC: see table 2 - voir tableau 2; MSC: multiplicative scatter correction - correction de dispersion mutiplicative; $\mathrm{R}^{2}$ : coefficient of multiple determination - coefficient de détermination; RMSEC: root mean standard error of calibration - erreur standard de calibration; RMSECV: root mean standard error of crosscalibration - erreur standard de validation croisée; RPD: ratio of prediction to deviation - rapport de prédiction à l'écart.

apple trees from cultivars differing in susceptibility to fire blight. Their results ranged from 2.42 to $3.82 \mathrm{mg} \cdot \mathrm{g}^{-1}$. Rana et al. (2016) evaluated the total phenolic compounds and total flavonols in leaves of M. domestica variety Red Chief. They found total phenolic compound values ranging from 12.50 to $30.38 \mathrm{mg} \cdot \mathrm{g}^{-1} \mathrm{DW}$ and total flavonol values of between 10.95 and $20.92 \mathrm{mg} \cdot \mathrm{g}^{-1} \mathrm{DW}$. Our results were higher than those reported by Sklodowska et al. (2017) and Rana et al (2016). Mikulic-Petkovsek et al. (2009) studied some individual phenolic compounds and total phenolic compounds in apple leaves (variety Golden Delicious scab-susceptible) after infection with apple scab. The total phenolic compound content ranged from around 45 to $60 \mathrm{mg} \cdot \mathrm{g}^{-1} \mathrm{DW}$. They also investigated the seasonal changes in total and individual phenolic compounds in leaves of scabresistant and susceptible apple cultivars for two years. They found total phenolic compound values ranging between 60 and $135 \mathrm{mg} \cdot \mathrm{g}^{-1} \mathrm{DW}$. They demonstrated that leaves of scab-resistant apple cultivars contained significantly more total phenolic compounds than those of susceptible apple cultivars. They also showed that the total phenolic compound content in the leaves depends on the cultivar (genotype) and on seasonal changes during the growing season. Our results were in the same range reported by these authors. Recently, Parvaneh et al. (2019) determined total phenolic compounds and total flavanols in leaves of Iranian red flesh apple cultivars. They found values ranging from of 74.3 to $127.03 \mathrm{mg} \cdot \mathrm{g}^{-1}$ for total phenolic compounds and from 23.37 to $25.59 \mathrm{mg} \cdot \mathrm{g}^{-1}$ for total flavanols. These values were higher than those observed in our study. The very high level of flavanols can be explained by the selected cultivars with the red flesh characteristic.

For P. communis (variety not specified), Zbigniew et al. (2014) investigated total phenolic compounds. They found a phenolic compound content very low $\left(28.2 \mathrm{mg} \cdot \mathrm{g}^{-1}\right)$ compared to the value observed in our study $\left(58.39 \mathrm{mg} \cdot \mathrm{g}^{-1}\right)$.

Amaral et al. (2010) investigated the influence of cultivar, geographical origin and ripening stage on the phenolic composition of hazelnut leaves. Total phenolic compounds ranged from 2.5 to $35 \mathrm{mg} \cdot \mathrm{g}^{-1}$. Oliveira et al. (2007) determined total phenolic compounds and $\mathrm{DPPH}$ values (expressed as $\mathrm{EC}_{50}$ ) in three cultivars of $C$. avellana leaves. Results obtained ranged from 37.72 to $44.00 \mathrm{mg} \cdot \mathrm{g}^{-1}$ for total phenolic compounds and from 0.164 to $0.203 \mathrm{mg}$ for DPPH antioxidant capacity. Amaral et al. (2005) analysed the phenolic compounds in ten different cultivars of hazelnut leaves. The level of these compounds ranged from 15.41 to $27.68 \mathrm{mg} \cdot \mathrm{g}^{-1}$. The values of total phenolic compounds reported by Amaral et al. (2010), Oliveira et al. (2007) and Amaral et al. (2005) were lower than those presented in this study $\left(77.34 \mathrm{mg} \cdot \mathrm{g}^{-1}\right)$. For DPPH antioxidant capacity, it was not possible to compare our results with those obtained by Oliveira et al. (2007) due to the difference in the expression of the results. Alasalvar et al. (2006) also investigated total phenolic compound content in extracts of hazelnut 
green leafy cover (C.avellana). The values obtained by the authors were very high and ranged from 156 to $201 \mathrm{mg} \cdot \mathrm{g}^{-1}$. These values were higher than those observed in this study.

Leaves of F. carica were also investigated by a few authors. Petruccelli et al. (2018) investigated ten Italian varieties of $F$. carica leaves. They quantified total phenolic compounds and antioxidant capacity (ORAC and DPPH). The concentration of phenolic compounds ranged from 16.22 to $38.91 \mathrm{mg} \cdot \mathrm{g}^{-1}$. The ORAC values reported by the authors were between 6.33 and $49.11 \mu \mathrm{MTE} \cdot \mathrm{g}^{-1}$. The DPPH results were expressed in term of $\mathrm{EC}_{50}$ and ranged between 0.48 and $6.68 \mathrm{mg} \mathrm{DW}$. Allahyari et al. (2014) also evaluated total phenolic compounds and total flavonols in leaves of $F$. carica. The levels of these bioactive compounds were $12.29 \mathrm{mg} \cdot 100 \mathrm{~g}^{-1}$ and $40.73 \mathrm{mg} \cdot \mathrm{g}^{-1}$ respectively. In the same way, the total phenolic compounds and ORAC antioxidant capacity of leaves from Tunisian figs were investigated by Ammar et al. (2015). The content of these compounds ranged from 618 to $790 \mathrm{mg} \cdot 100 \mathrm{~g} \mathrm{~g}^{-1}$ and from 1.32 to $1.66 \mathrm{mmol} \mathrm{ET} \cdot 100 \mathrm{~g}^{-1}$ respectively. Our results for the total phenolic compounds $\left(11.780 \mathrm{mg} \cdot \mathrm{g}^{-1}\right)$ were higher than those observed by Allahyari et al. (2014) and Ammar et al. (2015) but lower than those observed by Petruccelli et al. (2018). The total flavonol observed by Allahyari et al. (2014) was higher than those reported in this study $\left(6.54 \mathrm{mg} \cdot \mathrm{g}^{-1}\right)$. All antioxidant capacity values reported by authors were lower than those reported in our study.

The use of NIRS to determine total phenolic compounds and antioxidant capacity in leaves of fruit species has never been investigated up to date. However, this application has been largely studied for Camellia sinensis. As far as we know, Schulz et al. (1999) were the first to describe this application. They demonstrated that quality parameters such as total phenolic compound content could be determined simultaneously by one measurement, thereby providing a simple, rapid, reliable and low-cost way of characterizing green tea quality $\left(\mathrm{SECV}=1.93 \% ; \mathrm{R}_{\mathrm{CV}}^{2}=0.67\right)$. Chen et al. (2008) showed that NIR spectroscopy with chemometric approaches could be successfully applied to determine total phenolic compound content in green tea $(\mathrm{RMSECV}=1.06-1.52 \% ; \mathrm{RMSEP}=1.11$ $\left.-1.80 \% ; \mathrm{R}^{2}{ }_{\mathrm{CV}}=0.81-0.95 ; \mathrm{R}_{\text {PRED }}^{2}=0.64-0.87\right)$. Wang et al. (2015) also proposed a NIRS method to predict phenolic compound content in green tea with high precision (RMSECV: 0.36 - 0.68\%; RMSEP: $\left.0.27-0.62 \% ; \mathrm{R}_{\mathrm{CAL}}^{2}: 0.99-0.99 ; \mathrm{R}_{\mathrm{PRED}}^{2}: 0.95-0.99\right)$. In the same way, Ren et al. (2013) demonstrated that NIR spectroscopy can be successfully used for the rapid determination of phenolic compounds of black tea $\left(\mathrm{RMSECV}=0.55 \%\right.$; $\mathrm{RMSEP}=0.59 \% ; \mathrm{R}_{\mathrm{CAL}}^{2}=$ $\left.0.95 ; \mathrm{R}_{\text {PRED }}^{2}=0.91\right)$. Wang et al. (2018) were also able to predict phenolic compound content using NIRS in Chinese black, dark, oolong, and green teas (RMSEC: $0.35-1.48 \%$; RMSEP: $0.60-1.73 \%$; $\mathrm{R}_{\mathrm{CAL}}^{2}$ : $\left.0.963-0.998 ; R_{\text {PRED }}^{2}: 0.95-0.99\right)$. Our performance parameters were better than those found by Schulz et al. (1999). However, they were inferior to the high performances of the other investigations reported on tea. Compared to the studies dealing with other plant species (see introduction), our results were not as good as theirs. The performance parameters observed by these authors were better than those observed in this study. One hypothesis may be the particular sampling used here. In fact leaves of various fruit trees (gender, species and varieties) were analysed and the subsequent calibration models were developed considering all samples together, unlike most studies usually focussing on one species. In addition, a relatively low number of samples for each species were considered. It is likely that the different species may present different phenolic profiles (qualitatively and quantitatively) leading to a great variability in the data and to reduced calibration performances.

\section{CONCLUSIONS}

In this study, phenolic compounds (total phenolic compounds, total flavanols and total flavonols) and antioxidant capacity based on ET (DPPH) and HAT (ORAC) were quantified in leaves of fruit species commonly consumed in the world (P. avium, P. cerasus, M.domestica, P.domestica, P. communis, F. carica, $V$. vinifera and $C$. avellana of different varieties). These species were found to be important sources of phenolic compounds and antioxidants. Calibration models were developed using near-infrared spectroscopy and chemometric techniques in the quantification of phenolic compounds and antioxidant capacity. NIR spectroscopy coupled with chemometrics showed promise as a rapid and non-destructive method to estimate phenolic compounds and antioxidant capacity in these leaves that can also be used for screening purposes in phenolic content determination. However, the present results could be improved by increasing the sample size for each species and developing specific calibration models for each one.

\section{Bibliography}

Alasalvar C., Karamac M., Amarowicz R. \& Shahidi F., 2006. Antioxidant and antiradical activities in extracts of hazelnut kernel (Corylus avellana L.) and hazelnut green leafy cover. J. Agric. Food Chem., 54, 4826-4832, doi. org/10.1021/jf0601259

Allahyari S., Delazar A. \& Najafi M., 2014. Evaluation of general toxicity, anti-oxidant activity and effects of Ficus 
carica leaves extract on ischemia/reperfusion injuries in isolated heart of rat. Adv. Pharm. Bull., 4(2), 577-582.

Amaral J.S. et al., 2005. Phenolic profile of hazelnut (Corylus avellana L.) leaves cultivars grown in Portugal. Nat. Prod. Res., 19(2), 157-163, doi.org/10.1080/14786 410410001704778

Amaral J.S. et al., 2010. Phenolic composition of hazelnut leaves: influence of cultivar, geographical origin and ripening stage. Sci. Hortic., 126, 306-313, doi. org/10.1016/j.scienta.2010.07.026

Ammar S. et al., 2015. Assessment of the distribution of phenolic compounds and contribution to the antioxidant activity in Tunisian fig leaves, fruits, skins and pulps using mass spectrometry-based analysis. Food Funct., 6 , 3663-3677, doi.org/10.1039/c5fo00837a

Apak R. et al., 2007. Comparative evaluation of various total antioxidant capacity assays applied to phenolic compounds with the CUPRAC assay. Molecules, 12, 1496-1547.

Brand-Williams W., Cuvelier M.E. \& Berset E., 1995. Use of a free radical method to evaluate antioxidant activity. LWT Food Sci. Technol. Int., 28(1), 25-30, doi. org/10.1016/s0023-6438(95)80008-5

Can A. et al., 2018. The potential of near and mid-infrared spectroscopy for rapid quantification of oleuropein, total phenolics, total flavonoids and antioxidant activity in olive tree (Olea europaea) leaves. J. Food Meas. Charact., 12, 2747-2757, doi.org/10.1007/s11694-0189892-3

Chang C.C., Yang M.H., Wen H.M. \& Chern J.C., 2002. Estimation of total flavonoid content in propolis by two complementary colorimetric methods. J. Food Drug Anal., 10, 178-182, doi.org/10.38212/2224-6614.2748

Chen Q. et al., 2008. Determination of total polyphenols content in green tea using FT-NIR spectroscopy and different PLS algorithms. J. Pharm. Biomed. Anal., 46, 568-573, doi.org/10.1016/j.jpba.2007.10.031

de Rijke E. et al., 2006. Analytical separation and detection methods for flavonoids. J. Chromatogr. A, 1112, 31-63, doi.org/10.1016/j.chroma.2006.01.019

Delcour J.A. \& Devarebeke D.J., 1985. A new colorimetric assay for flavonoids in pilsner beers. J. Inst. Brew., 91, 37-40, doi.org/10.1002/j.2050-0416.1985.tb04303.X

Dong W., Ni Y. \& Kokot S., 2014. A novel near-infrared spectroscopy and chemometrics method for rapid analysis of several chemical components and antioxidant activity of mint (Mentha haplocalyx Briq.) samples. Appl. Spectrosc., 68(2), 245-254, doi.org/10.1366/1307091

Floegel A. et al., 2011. Comparison of ABTS/DPPH assays to measure antioxidant capacity in popular antioxidantrich US foods. J. Food Compos. Anal., 24, 1043-1048, doi.org/10.1016/j.jfca.2011.01.008

Frizon C.N.T. et al., 2015. Determination of total phenolic compounds in yerba mate (Ilex paraguariensis) combining near-infrared spectroscopy (NIR) and multivariate analysis. LWT J. Food Sci. Technol., 60 , 795-801, doi.org/10.1016/j.lwt.2014.10.030

Huang D.J. et al., 2002. High throughput assay of oxygen radical absorbance capacity (ORAC) using a multichannel liquid handling system coupled with a microplate fluorescence reader in 96-well format. J. Agric. Food Chem., 50, 4437-4444, doi.org/10.1021/ jf0201529

Ignat I., Volf I. \& Popa V.I., 2011. A critical review of methods for characterization of polyphenolic compounds in fruits and vegetables. Food Chem., 126, 1821-1835, doi.org/10.1016/j.foodchem.2010.12.026

Joubert E., Manley M. \& Botha M., 2006. Use of NIRS for quantification of mangiferin and hesperidin contents of dried green honeybush (Cyclopia genistoides) plant material. J. Agric. Food Chem., 54, 5279-5283, doi. org/10.1021/jf0606171

Kalinowska M. et al., 2014. Apples: content of phenolic compounds vs. variety, part of apple and cultivation model, extraction of phenolic compounds, biological properties. Plant Physiol. Biochem., 84, 169-188, doi. org/10.1016/j.plaphy.2014.09.006

Lorenzo J.M. \& Munekata P.E.S., 2016. Phenolic compounds of green tea: health benefits and technological application in food. Asian Pac. J. Trop. Biomed., 6(8), 709-719, doi.org/10.1016/j. apjtb.2016.06.010

Ma L. et al., 2016. The rapid determination of total polyphenols content and antioxidant activity in Dendrobium officinale using near-infrared spectroscopy. Anal. Methods, 8, 4584-4589.

MacDonald-Wicks L.K., Wood L.G. \& Garg M.L., 2006. Methodology for the determination of biological antioxidant capacity in vitro: a review. J. Sci. Food Agric., 86, 2046-2056, doi.org/10.1002/jsfa.2603

Mikulic-Petkovsek M., Stampar F. \& Veberic R., 2009. Seasonal changes in phenolic compounds in the leaves of scab-resistant and susceptible apple cultivars. Can. J. Plant Sci., 89, 745-753, doi.org/10.4141/cjps08202

Minet O., Decruyenaere V., Godin B. \& Baeten V., 2021. Application of NIR spectroscopy to the analysis of forages. In: Ciurczak E.W., Igne B., Workman J. \& Burns D.A., eds. Handbook of near-infrared analysis. $4^{\text {th }}$ ed. CRC Press.

Naczk M. \& Shahidi F., 2006. Phenolics in cereals, fruits and vegetables: occurrence, extraction and analysis. J. Pharm. Biomed. Anal., 41, 1523-1542, doi. org/10.1016/j.jpba.2006.04.002

Nicolaï B.M. et al., 2007. Nondestructive measurement of fruit and vegetable quality by means of NIR spectroscopy: a review. Postharvest Biol. Technol., 46(2), 99-118, doi. org/10.1016/j.postharvbio.2007.06.024

Oliveira I. et al., 2007. Hazel (Corylus avellana L.) leaves as source of antimicrobial and antioxidative compounds. Food Chem., 105, 1018-1025, doi.org/10.1016/j. foodchem.2007.04.059 
Osborne B.G., 2006. Near-infrared spectroscopy in food analysis. In: Encyclopedia of analytical chemistry: applications, theory and instrumentation. Online. John Wiley \& Sons, Ltd.

Ou B.X., Hampsch-Woodill M. \& Prior R.L., 2001. Development and validation of an improved oxygen radical absorbance capacity assay using fluorescein as the fluorescent probe. J. Agric. Food Chem., 49, 46194626, doi.org/10.1021/jf010586o

Parvaneh T., Abedi B., Davarynejad G.H. \& Moghadam E.G., 2019. Enzyme activity, phenolic and flavonoid compounds in leaves of Iranian red flesh apple cultivars grown on different rootstocks. Sci. Hortic., 246, 862-870, doi.org/10.1016/j.scienta.2018.11.034

Petruccelli R., Ieri F., Ciaccheri L. \& Bonetti A., 2018. Polyphenolic profiling and chemometric analysis of leaves from Italian Ficus carica L. varieties. Polyphenol compounds in common fig. Eur. J. Hortic. Sci., 83(2), 94-103, doi.org/10.17660/ejhs.2018/83.2.5

Rana S. et al., 2016. Phenolic constituents from apple tree leaves and their in vitro biological activity. Ind. Crops Products, 90, 118-125, doi.org/10.1016/j. indcrop.2016.06.027

Ren G. et al., 2013. Quantitative analysis and geographical traceability of black tea using Fourier transform nearinfrared spectroscopy (FT-NIRS). Food Res. Int., 53, 822-826, doi.org/10.1016/j.foodres.2012.10.032

Robards K. et al., 1999. Phenolic compounds and their role in oxidative processes in fruits. Food Chem., 66, 401436, doi.org/10.1016/s0308-8146(99)00093-x

Schulz H. et al., 1999. Application of near-infrared reflectance spectroscopy to the simultaneous prediction of alkaloids and phenolic substances in green tea leaves. J. Agric. Food Chem., 47, 5064-5067, doi.org/10.1021/ jf9813743

Silva E.M. et al., 2007. Antioxidant activities and polyphenolic contents of fifteen selected plant species from the Amazonian region. Food Chem., 101, 10121018, doi.org/10.1016/j.foodchem.2006.02.055

Sinelli N. et al., 2008. Evaluation of quality nutraceutical content of blueberries (Vaccinium corymbosum L.) by near and mid-infrared spectroscopy. Postharvest Biol. Technol., 50, 31-36, doi.org/10.1016/j. postharvbio.2008.03.013
Singleton V.L. \& Rossi J.A., 1965. Colorimetry of total phenolics with phosphomolybdic-phosphotungstic acid reagents. Am. J. Enol. Vitic., 16, 144-158.

Sklodowska M. et al., 2017. Phenolic profiles in apple leaves and the efficacy of selected phenols against fire blight (Erwinia amylovora). Eur. J. Plant Pathol., 151, 213-228, doi.org/10.1007/s10658-017-1368-5

Souza M. et al., 2017. Predição dos teores de compostos fenólicos e flavonoides na parte aérea das espécies Secale cereale L., Avena strigosa L. e Raphanus sativus L. por meio de espectroscopia no infravermelho próximo (NIR). Quim. Nova, 40(9), 1074-1081, doi. org/10.21577/0100-4042.20170120

Toledo-Martín E.M. et al., 2017. Rapid and cost-effective quantification of glucosinolates and total phenolic content in rocket leaves by visible/near-infrared spectroscopy. Molecules, 22, 851, doi.org/10.3390/ molecules22050851

Wang X., Huang J., Fana W. \& Lu H., 2015. Identification of green tea varieties and fast quantification of total polyphenols by near-infrared spectroscopy and ultraviolet-visible spectroscopy with chemometric algorithms. Anal. Methods, 7, 787-792, doi.org/10.1039/ c4ay02106a

Wang J. et al., 2018. Enhanced cross-category models for predicting the total polyphenols, caffeine and free amino acids contents in Chinese tea using NIR spectroscopy. LWT Food Sci. Technol., 96, 90-97, doi.org/10.1016/j. lwt.2018.05.012

Wu D. et al., 2012. Application of near-infrared spectroscopy for the rapid determination of antioxidant activity of bamboo leaf extract. Food Chem., 135, 2147-2156, doi. org/10.1016/j.foodchem.2012.07.011

Zbigniew S. et al., 2014. Antimicrobial and antiradical activity of extracts obtained from leaves of three species of the genus Pyrus. Microb. Drug Resist., 20(4), 337343, doi.org/10.1089/mdr.2013.0155

Zhang C. et al., 2008. Nondestructive prediction of total phenolics, flavonoid contents, and antioxidant capacity of rice grain using near-infrared spectroscopy. J. Agric. Food Chem., 56, 8268-8272, doi.org/10.1021/jf801830z

(46 ref.) 